\title{
Teorema matematika dalam perancangan desain
}

\author{
Baskoro Suryo Banindro,"
}

Jurusan Desain, Institut Seni Indonesia Yogyakarta, Indonesia

\begin{abstract}
World industry flourished and grown rapidly in all fields, as a piece of design, scattered in the discipline of interior design, graphic design, fashion design, product design, craft industry. But behind the glorious and legends in the design is not much known about the Chronicle and its struggle would be a mathematical theorem. Through this small scale study tries to analyze flashbacks oversize presence behind the creation of the design. With the approach of a mathematical theorem how do stories, it was created and in what form is present in the design?
\end{abstract}

Keywords: mathematical theorems, applications in industrial design

\begin{abstract}
Abstrak
Dunia industri berkembang dengan pesat dan menyeruak ke segala format, sebagai ilmu sebidang, desain terpencar dalam disiplin desain interior, desain grafis, desain fashion, kriya desain, desain produk industri. Namun dibalik kejayaan dan legenda dalam desain tidak banyak diketahui orang tentang kronik dan pergumulannya akan teorema matematika. Melalui kajian skala kecil ini mencoba mengulas kilas balik hadirnya kebesaran di balik penciptaan desain. Dengan pendekatan approach stories, tulisan ini fokus pada telaah bagaimanakah teorema matematika itu diciptakan dan dalam bentuk apa hadir dalam desain?
\end{abstract}

Kata kunci: teorema matematika, aplikasi dalam industrial desain

\section{Pendahuluan}

Tidak banyak diketahui umum bahwa di dalam dimensi ruang visual tersusun atas problematika matematika. Semua yang mendasari itu telah diketemukan teorema matematika sebelum Tarik Isa Almasih, dan penemuan itu telah melahirkan apa yang dirasakan oleh kehidupan modern milenia kini. Melalui kajian approach stories, akan dibahas teorema matematika terkait dengan sejarah yang mengawali dan tokoh yang mengkreditkan penemuan itu sehingga terpateri dalam dunia industri. Ada beberapa teorema yang akan dibahas, antara lain fraktal, rekursif, teorema Pitagoras, Fibonacci, Mandelbrot, dan Geometris Logo.

Fraktal adalah suatu bentuk kurva tak reguler atau suatu pola dimana satu bagian kecil dari keseluruhan kurva itu sama dengan bentuk dari sebagian kecil yang lain atau bentuk yang lebih besar atau bahkan bentuk keseluruhan kurva yang direduksi atau diperkecil hingga seukuran dengan satu bagian tertentu tersebut (Barnsley, 1993). Nama umum untuk struktur benda geometris, salah satunya adalah kurva monster (benda asing yang tidak dikenal) misalnya bunga salju Koch (Harris dkk, 1998). Serpihan salju berwarna putih terbuat dari es murni (Gambar 1). Munculnya paparan warna putih dikarenakan refleksi difus dari seluruh spektrum cahaya pada kristal kecil (Lawson, 2001). Fraktal banyak digunakan sebagai pengembangan salah satu pendekatan visual, dimana komposisi objek, di dasarkan oleh pengulangan pola (pattern) yang sama pada ornamennya, dengan modifikasi berbagai skala yang berbeda-beda, dan modifikasi yang lain dengan cara di flip/mirroring, diputar (rotating) serta digabung (intersecting), rekursif, sehingga menampilkan komposisi bentuk yang menarik.

\footnotetext{
* Koresponden penulis e-mail : banindro@yahoo.com
} 

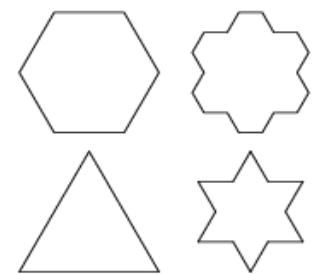

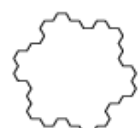

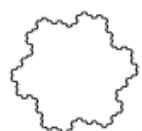<smiles>C1CCCCCCCCCCCCCCCCC1</smiles><smiles>C1CCCCCCCCCCC1</smiles>

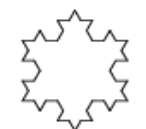

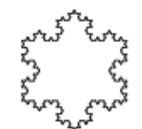<smiles>C1CCCCCC1</smiles>

Gambar 1. Gambaran proses pembentukan bunga salju (Sumber: https://kristal+salju+koch+html )
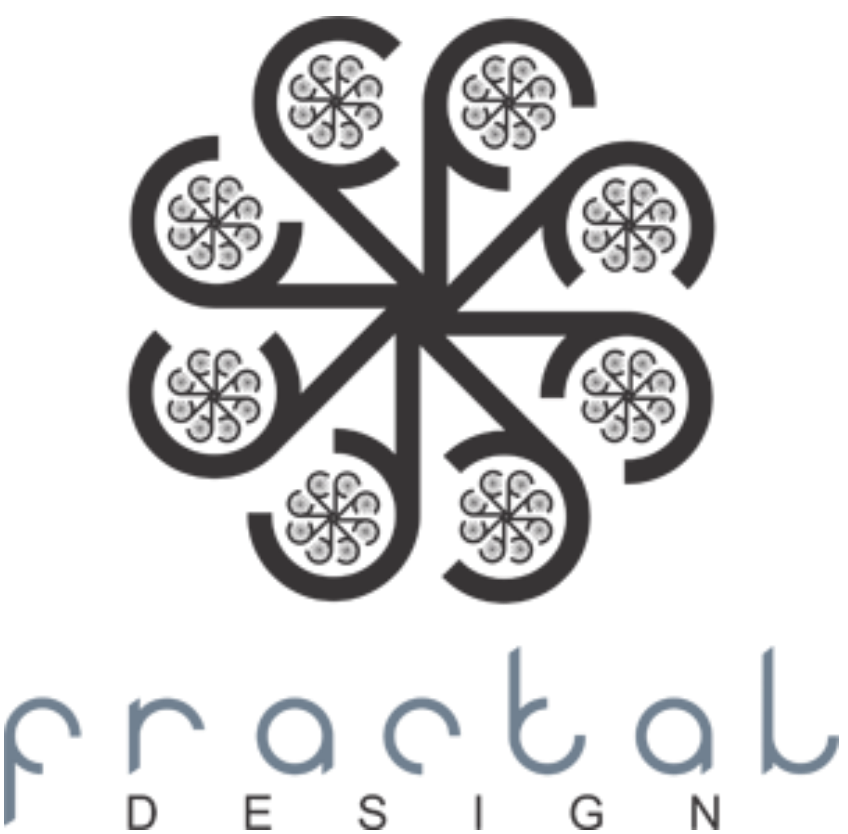

Gambar 2. Pembentukan kristal bunga salju menurut Koch

(Sumber: http://keindahan-keindahan-fraktal-html)

\section{Bahan dan Metode}

Penelitian ini menggunakan teknik studi literatur untuk melaksanakannya. Studi literatur merupakan metode penyelesaian masalah dengan cara menelusuri sumber-sumber tulisan yang sudah pernah dibuat sebelumnya. Studi literatur ini sering disebut pula studi pustaka. Dari 4 cara melaksanakan studi literatur, seperti mengupas (criticize), membandingkan (compare), meringkas (summarize), dan mengumpulkan (synthesize) suatu literatur, penulis memilih mengupas (critize) topik-topik dalam teorema matematika dan membandingkan (compare) dengan aplikasinya di dunia desain, khususnya desain produk.

\section{Hasil dan pembahasan}

Fraktal muncul dalam berbagai bentuk. Salah satunya adalah rekursif. Rekursif merupakan proses pengulangan item dengan cara kesamaan-diri. Penggunaan paling umum dari rekursi yaitu dalam matematika dan ilmu komputer, dimana ia mengacu kepada suatu metode mendefinisikan fungsi dengan menggunakan objeknya sendiri (Hofstadter, 2006).

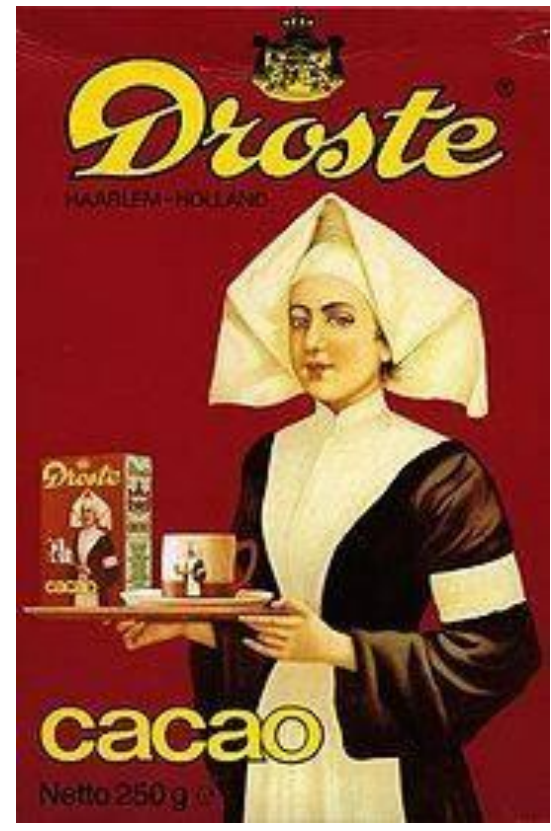

Gambar 3. Droste effect

Dalam gambar ini ada gambar ini lagi yang di dalamnya ada gambar ini lagi dan seterusnya sampai kedalaman tak terbatas.

(Sumber: andiagusta_rekursif.html)
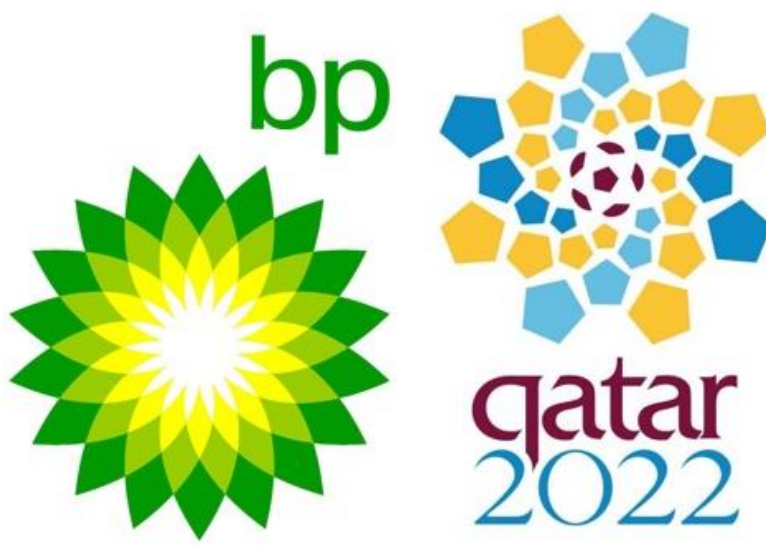

Gambar 4. Circular pattern, sebagai bagian dari wujud rekursif diterapkan pada logo BP dan liga sepak bola dunia di Qatar (Sumber:https:/free-vector-circular-pattern)

Rekursif adalah konsep pengulangan yang penting dalam ilmu komputer. Konsep ini dapat digunakan 
untuk merumuskan solusi sederhana dalam sebuah permasalahan yang sulit untuk diselesaikan secara iteratif dengan menggunakan loop for, while do. Pada saat tertentu konsep ini dapat digunakan untuk mendefinisikan permasalahan dengan konsisten dan sederhana (Agusta, 2014).
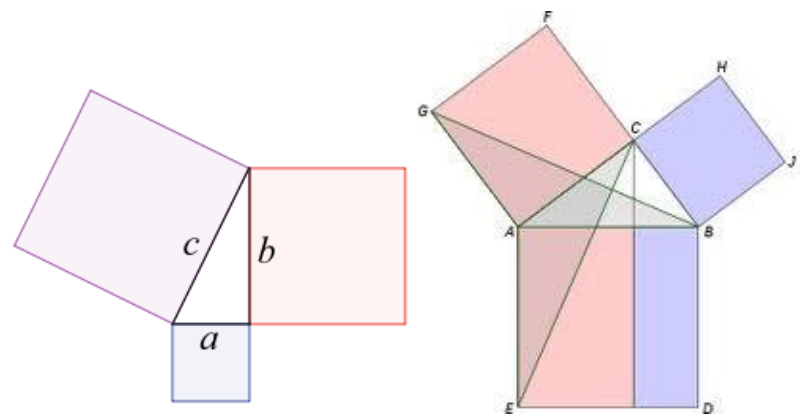

Gambar 5. Rumus golden age segitiga pitagoras. (Sumber:http://www.blackcatt/teorema-pythagoras )

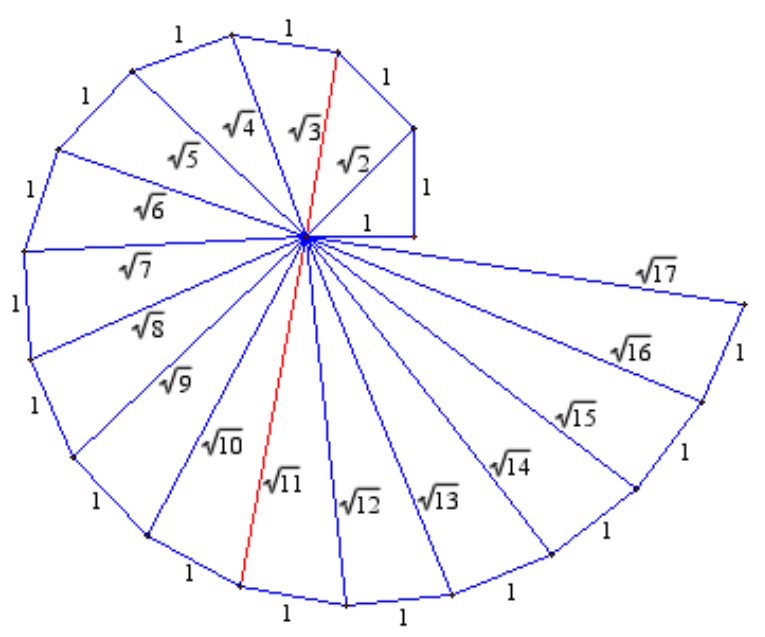

Gambar 6. Segitiga golden triangle (Sumber:http://blackcatt/teorema-pythagoras)

Teorema matematika lainnya adalah Pohon Pitagoras. Pohon Pitagoras ditemukan oleh seorang guru matematika Belanda Albert E. Bosman pada tahun 1942, diberi nama sesuai penemu rumus ahli matematika Yunani Pitagoras, Rumus Pitagoras pada skala perbandingan menghasilkan pola organis yang estetis, yakni dengan dalil umum matematikanya yang menyatakan bahwa kuadrat hipotenusa dari suatu segitiga siku-siku adalah sama dengan jumlah kuadrat dari kaki-kakinya (sisi-sisi siku-sikunya). Walaupun fakta di dalam teorema ini telah banyak diketahui sebelum lahirnya Pythagoras, namun teorema ini dikreditkan kepada Pythagoras karena ia yang pertama kali membuktikan pengamatan ini secara matematis (Singh, 1998).

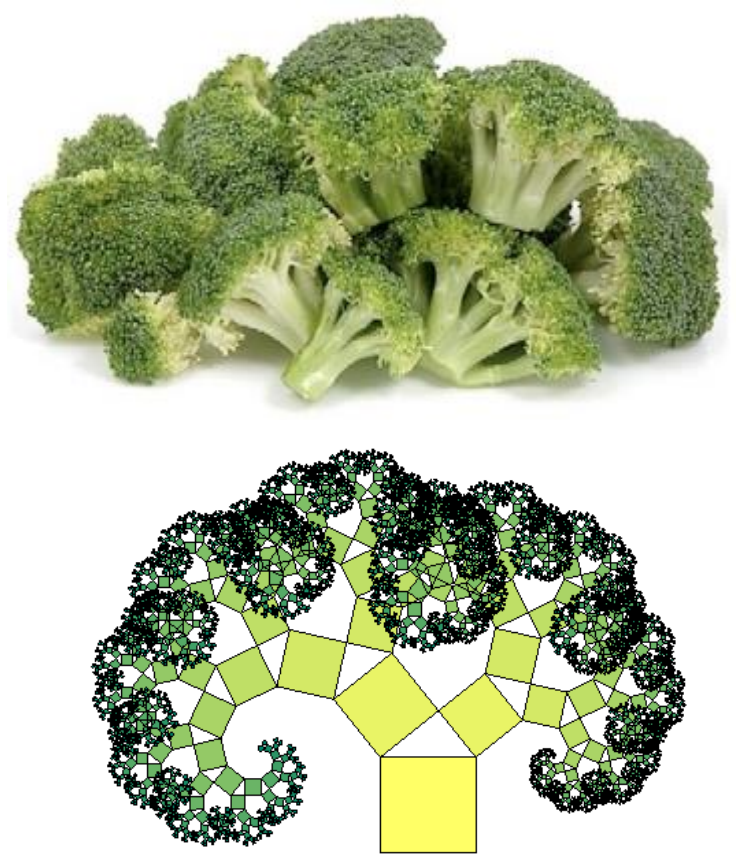

Gambar 7. Kesatuan organik yang tersusun atas segitiga Pitagoras. (Sumber: De ware geschiedenis van de Boom van Phytagoras)
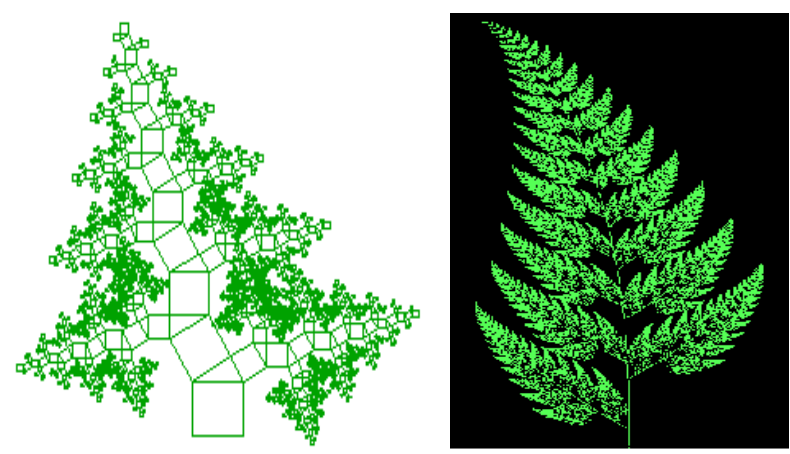

Gambar 8. Struktur fraktal Pitagoras pada daun asparagus (Sumber: http://www.bitinventions.com/index.php/noticias )

Rumus matematika Fibonacci pada skala perbandingan menghasilkan golden spiral ratio memancar yang estetis. Gambar yang simetris dan mentakjubkan, tersusun atas ciptaan alamiah fraktal alam. Objeknya terlihat sangat matematis, dan perwujudannya sama dimana-mana sehingga sering disebut wujud geometris yang sakral. Pramana (2015) mengatakan bahwa barisan bilangan Fibonacci pertama kali dikemukakan oleh Leonardo Pisano atau 
lebih dikenal sebagai Fibonacci. Ia menemukan rumus matematika $F_{n}=F_{n-1}+F_{n-2}$, apabila digambarkan dalam media gambar maka muncullah gambar atau objek yang sangat menakjubkan secara optis dan struktural (Gambar 9, 10, dan 11).

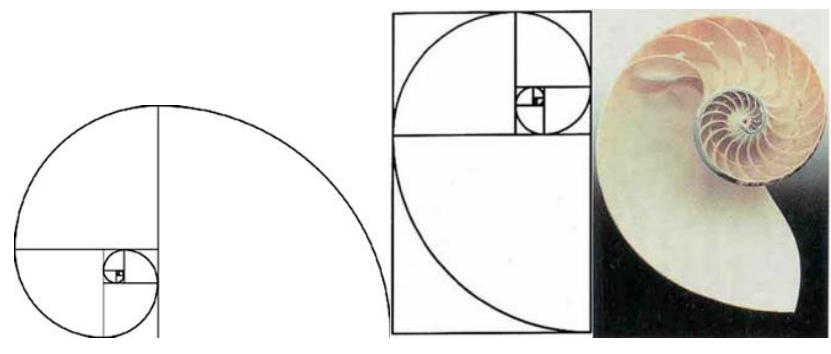

Gambar 9. Fibonacci golden ratio (Sumber: http://fractalfoundation.org/OFC/OFC-11-2.html)

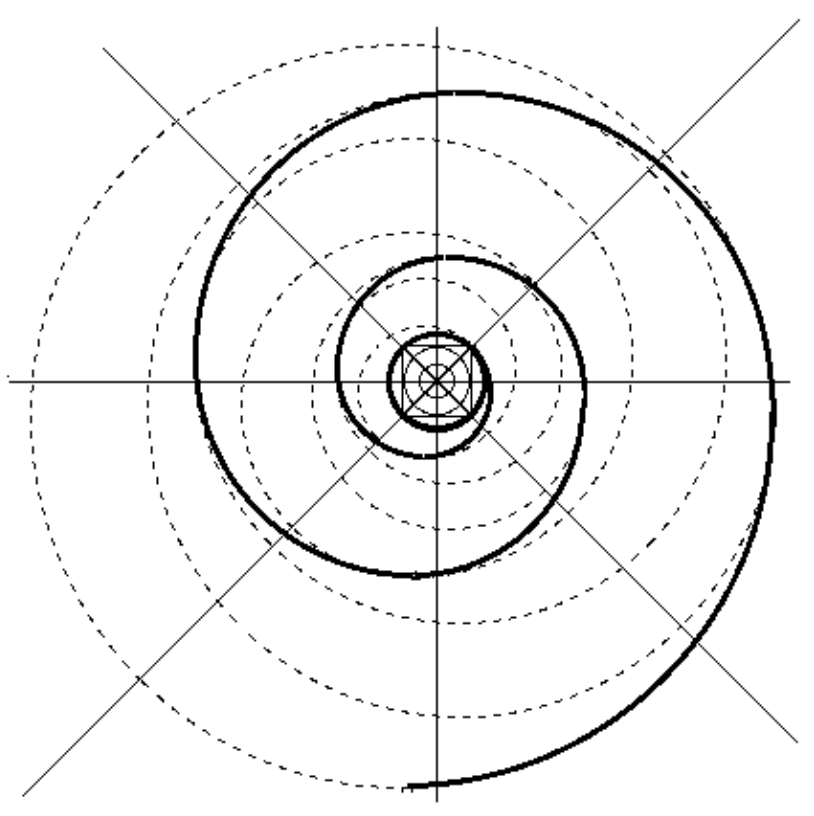

Gambar 10. Circle ratio

(Sumber: http://fractalfoundation.org/OFC/OFC-11-2.html )

Commonwealth Games atau pesta olahraga negaranegara persemakmuran ke-19 yang dihelat di New Dehli, India pada tahun 2010 selain mengangkat binatang khas India, harimau sebagai mascot yang disebut Shera, juga memunculkan logo yang cukup unik yang dirancang menggunakan teorema matematika Fibonacci. Hal tersebut diperlihatkan pada Gambar 12 berikut ini.

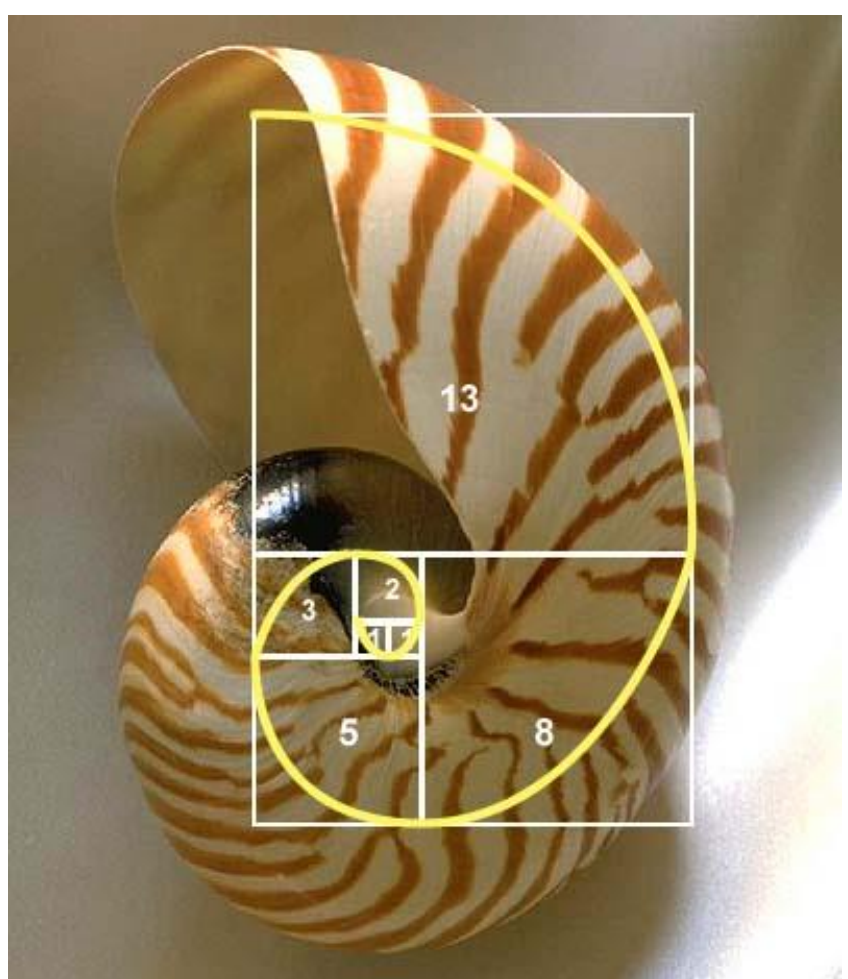

Gambar 11. Objek alami dari rumah siput Fibonacci (Sumber:http://lavoisierthewinner.blogspot.co.id/ hubungan-pola-alam-dan-matematika.htm)

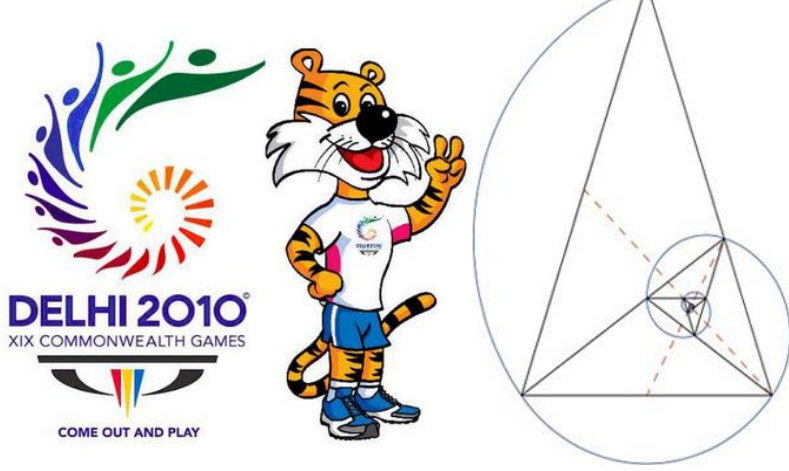

Gambar 12. Logo Commonwealth Games 2010 dirancang dengan menggunakan matematika Fibonacci.

(Sumber: XIX Commonwealth Games 2010 Delhi Official Website)

Teori moderen pembentukan fraktal ditemukan oleh Benoît Mandelbrot pada tahun 1975, Mandelbrot disebut-sebut sebagai bapak geometri fraktal. Ia telah berhasil mengembangkan teori yang telah dicetuskan oleh para matematikawan klasik dan mampu memberi gambaran yang jelas mengenai bentuk fraktal dan salah satu caranya adalah lewat bantuan perhitungan matematika dengan komputer (Gambar 13). Kini 
rumusan notasi coding matematika ini diterapkan ke aplikasi fraktal batik moderen (Mandelbrot, 2006).

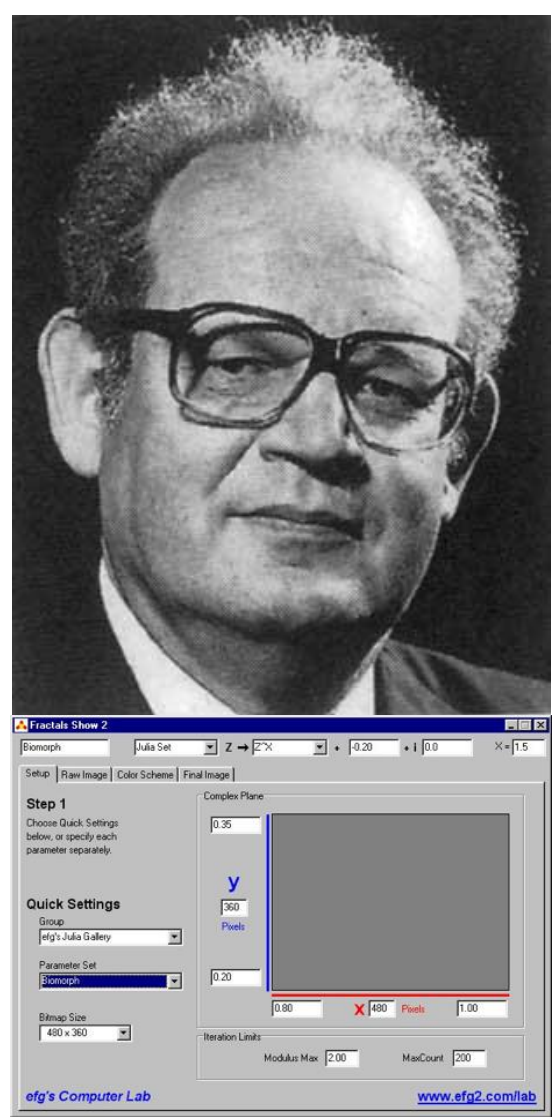

Gambar 13. Benoît Mandelbrot (atas), dan Koordinat fraktal moderen Mandelbrot dalam software (bawah)

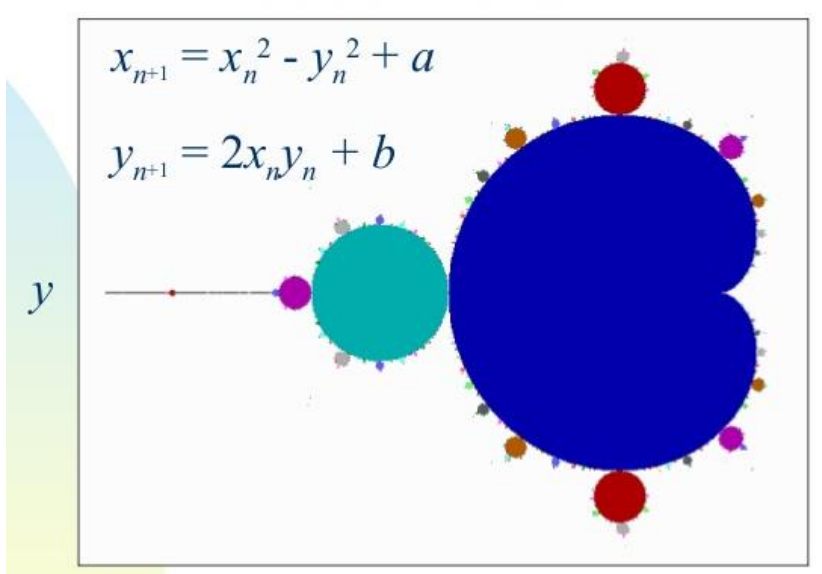

$x$

Gambar 14. Rumus matematika Mandelbrot untuk merancang fraktal desain

(Sumber:https://www.google.com.mandelbrot+set)
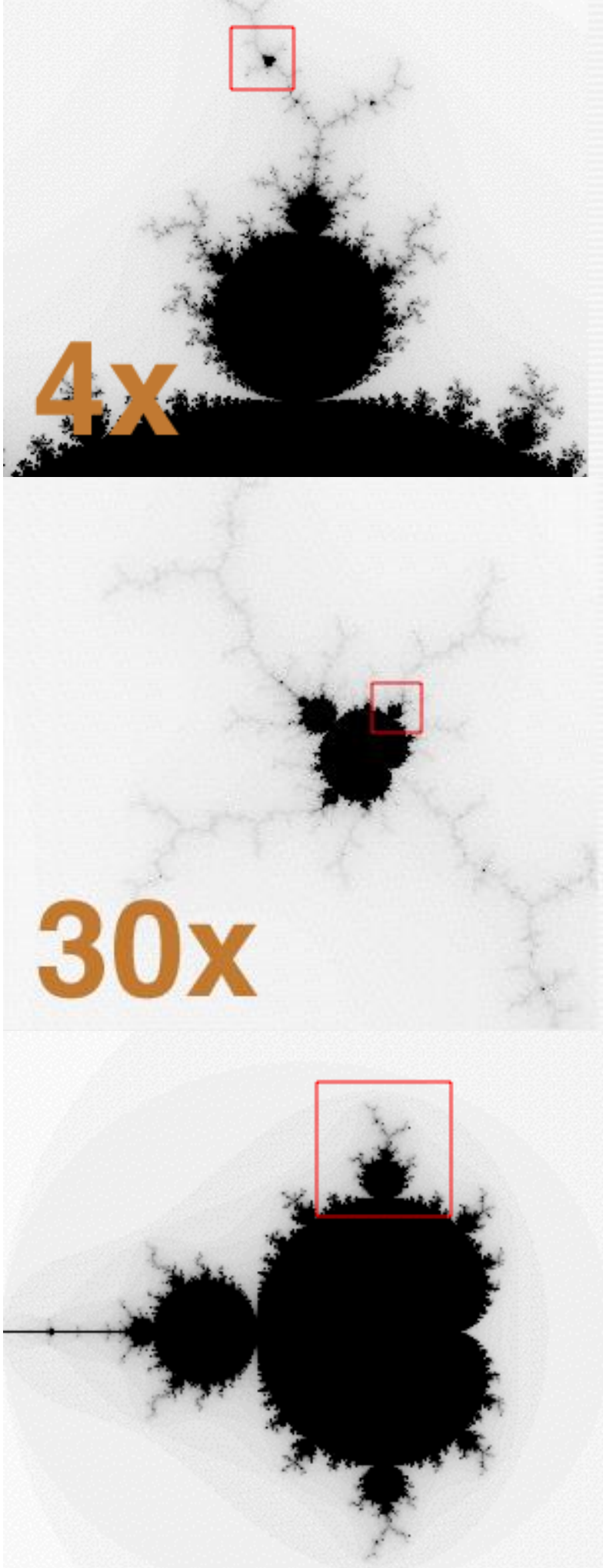

Gambar 15. Perbesaran noktah tinta yang tersusun atas duplikasi objek itu sendiri. (Sumber: http://www.wikiwand.com/id/Fraktal) 


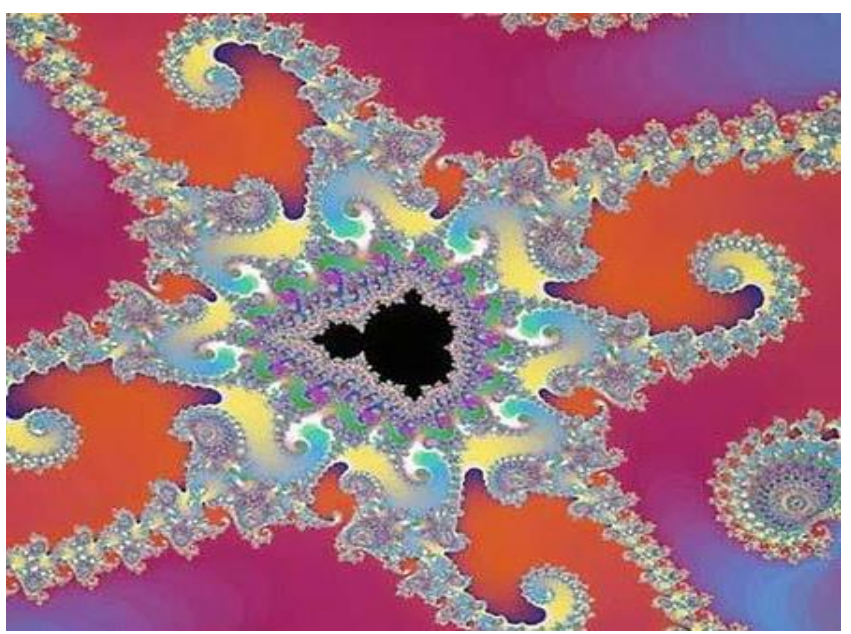

Gambar 16. Objek fraktal Mandelbrot pada batik moderen (Sumber:Mandelbrot_set\#/media/File:Mande 1_zoom_06_double_hook.jpg)

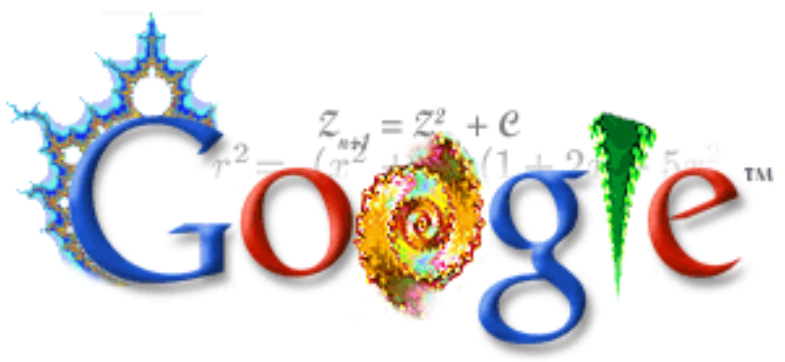

Gambar 17. Aplikasi fraktal Mendelbrot didedikasikan untuk identitas Google (Sumber:https://www.google.com/imgresomadrawbridge)

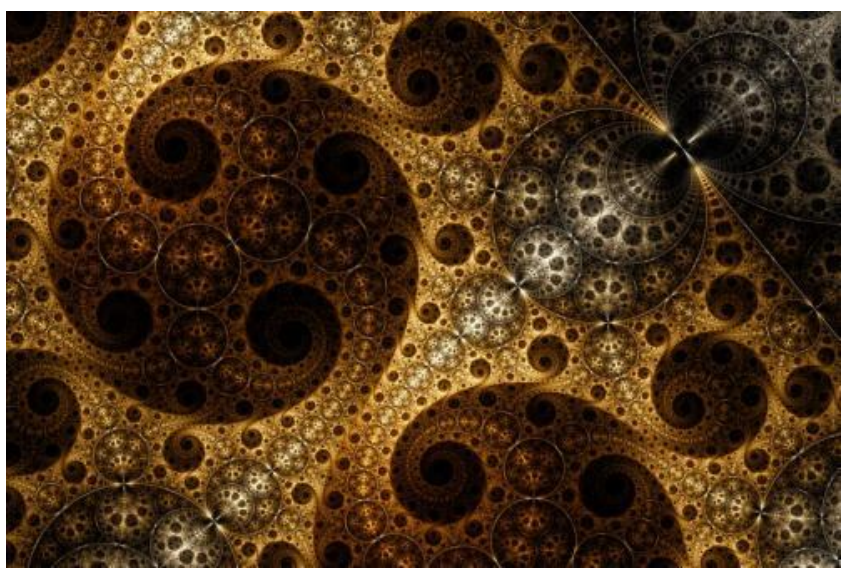

Gambar 18. Aplikasi batik fraktal dengan software khusus. (Sumber: http://www/batik-fraktal -matematika-komputer)

\section{Pola Geometris pada Logo}

Pola geometris saat digunakan dengan benar dapat sangat fleksibel, secara visual dan efektif dalam beberapa kasus, sangat fungsional. Anda dapat menggunakan mereka untuk membawa mengakui vibrasi kehidupan dan untuk desain anda atau keanggunan yang lebih lembut dan style untuk mereka. Pola geometris adalah cara terbaik untuk meraih banyak perhatian, tetapi jika anda berencana untuk menggunakan atau menggabungkan banyak dari mereka, menganggap menyeimbangkan mereka keluar dengan beberapa kurang-elemen-elemen sibuk. Bentuk geometris dapat kuat, terlihat lebih bold dan elemenelemen desain yang menakjubkan, jadi secara alamiah mereka bekerja menelaah dalam dunia logo (Stribley, 2015).

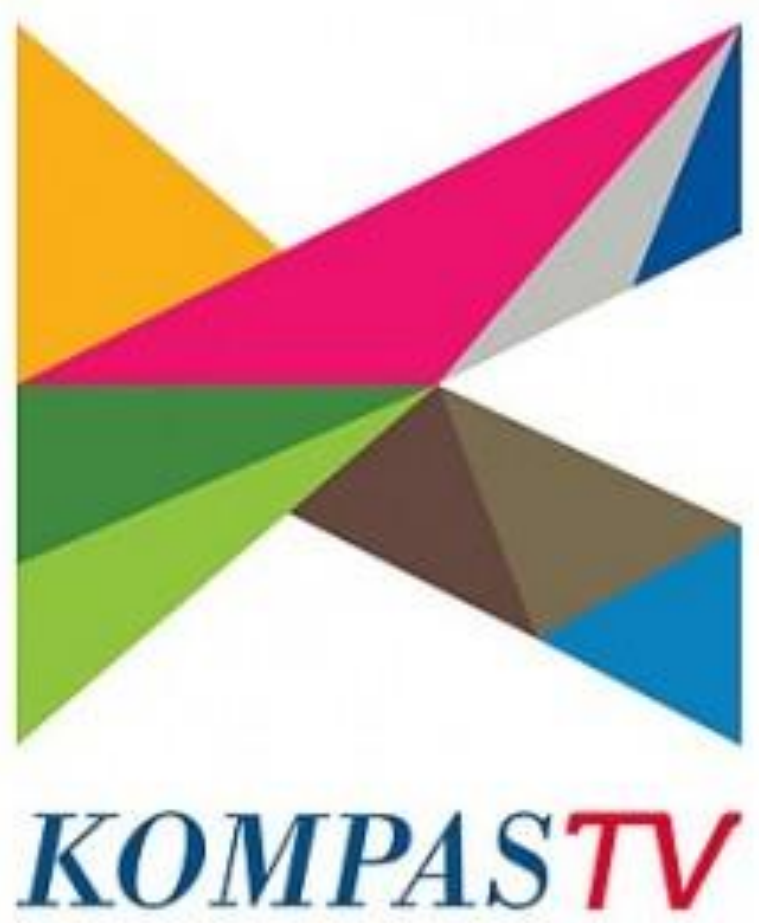

Gambar 19. Logo Kompas TV

yang digunakan resmi sejak tahun 2012

(Sumber: http://www. /sejarah-dan-logo-televisi-di-indonesia)

Kompas TV adalah salah satu stasiun televisi swasta terestrial nasional di Indonesia menggunakan logo "museo biru merah". Dengan dominasi figur huruf K yang mencolok, fraktal berbasis geometris segitiga dengan kombinasi warna-warni "pelangi" lebih identik dan mendekatkan dengan warna lokal budaya di nusantara (Nirvana, 2014).

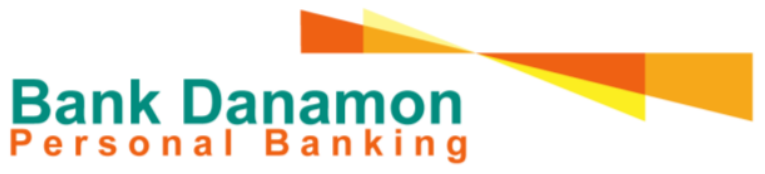

Gambar 20. Logo Bank Danamon (Sumber:http://dgi-indonesia.com) 
Bentuk logo lain yang menggunakan pola geometris adalah logo Bank Danamon. Logo Bank Danamon tersebut tersusun atas bentuk atau pola geometris logo, dengan konsep "mercu-suar". Kombinasi warna-warni orange dan merah adalah simbol cahaya lampu malam suar yang terkomposisi dalam objek segitiga geometris (Gambar 20).

Logo tiketdomestik.com jika dianalisis juga menggunakan pola-pola geometris pada bagian nonteks-nya. Tiketdomestik.com adalah sebuah sistem informasi jadwal dan harga tiket pesawat untuk maskapai penerbangan Indonesia. Situs ini dikelola secara mandiri untuk membantu para calon penumpang mendapatkan informasi yang tepat, akurat, dan cepat. Untuk menggambarkan kinerja tersebut, maka logo diwujudkan dalam bentuk ikon pesawat terbang (kertas) dengan fraktal geometris dengan warna-warni yang menggambarkan hiruk pikuk maskapai penerbangan dengan berbagai tujuan destinasi dan hiruk pikuk nya kota wisata (Gambar 21).

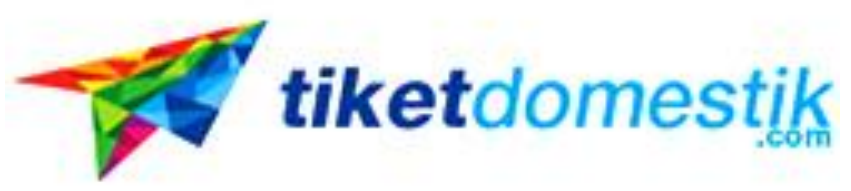

Gambar 21. Logo Tiket Domestik

(Sumber: www.tiketdomestik.com)

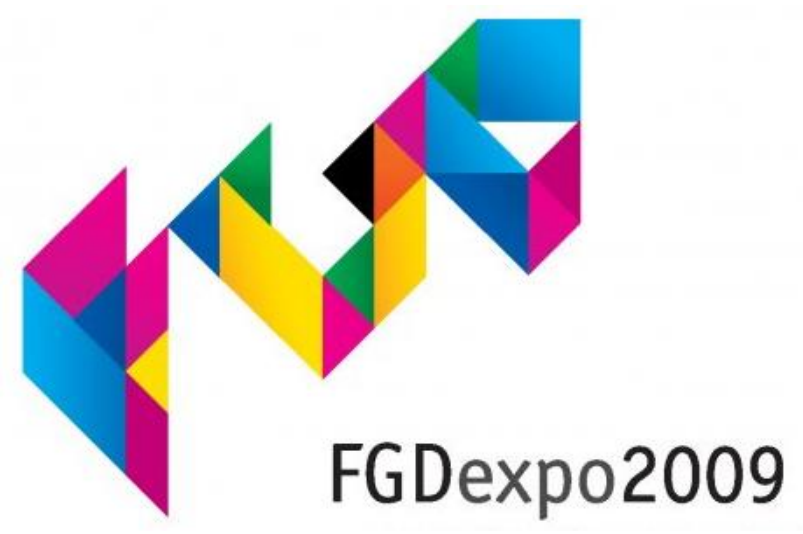

Gambar 22. Logo FGDexpo2009

(Sumber: dgi-indonesia.com)

Pola geometris juga digunakan dalam Logo FGDecpo 2009. FGDexpo (Forum Grafika Digital) expo 2009 adalah sebuah even pameran grafika terbesar di Indonesia yang melibatkan produsen, distributor, penyedia produk dan jasa grafika, asosiasi perusahaan dan profesi, institusi pendidikan, dan mitra luar negeri.. Logo yang dirancang oleh Karakter yang didesain oleh Mendiola B. Wirawan ini terlihat dinamis. Terkomposisi atas 3 bidang pola masingmasing mewakili 3 pilar industri kreatif (dari 14 pilar industri kreatif yang telah ditetapkan Pemerintah), yakni: packaging, promotion, dan publishing (Satvika, 2009).

\section{Fraktal Dalam Aplikasi Desain Industri}

Studi desain modern menerapkan bentuk kompleks dan geometri fraktal untuk membuat jenis-jenis baru benda-benda yang memiliki bentuk masa depan. Di bawah ini beberapa contoh rancangan industri bendabenda yang dianalisis menggunakan kompleksitas dan fraktal geometri.

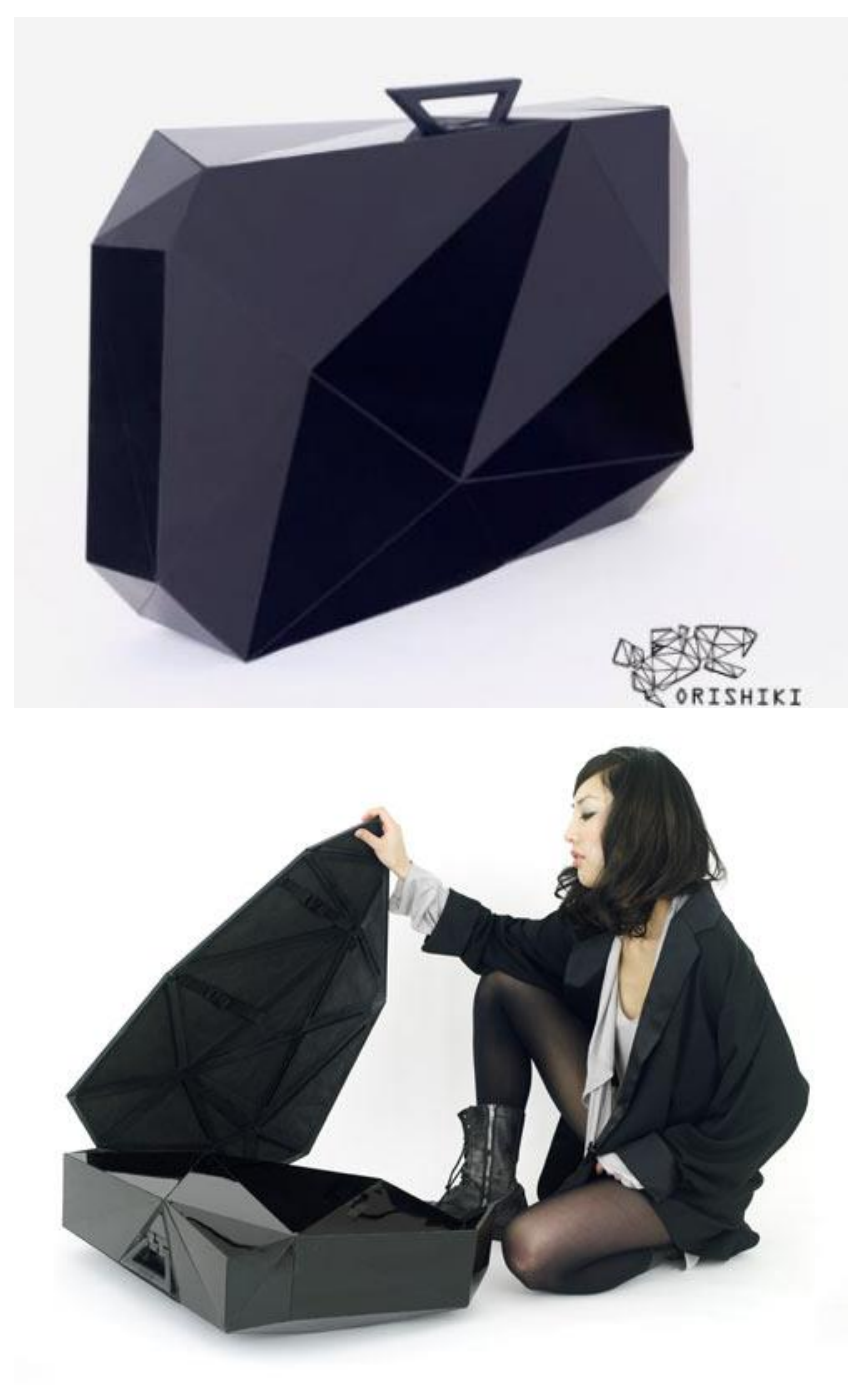

Gambar 23. Tas fraktal, selain futuristik, tas ini juga dapat dilipat menjadi lembaran tipis.

(Sumber: http://www.itsliquid.com/orishiki-naokikawamoto.html)

Tas fraktal geometris yang dirancang oleh desainer Jepang, Naoki Kawamoto ini diberi nama tas Orishiki. 
Tas ini berbentuk koper kreatif yang dapat diratakan dan dilipat kembali ke bungkusnya yang keras, faceted. Koper tiga-dimensi ini juga dilengkapi dengan interior sutra lembut dan akan menyimpan benda berharga tetap di tempatnya (http://www.itsliquid.com/orishikinaoki-kawamoto.html).

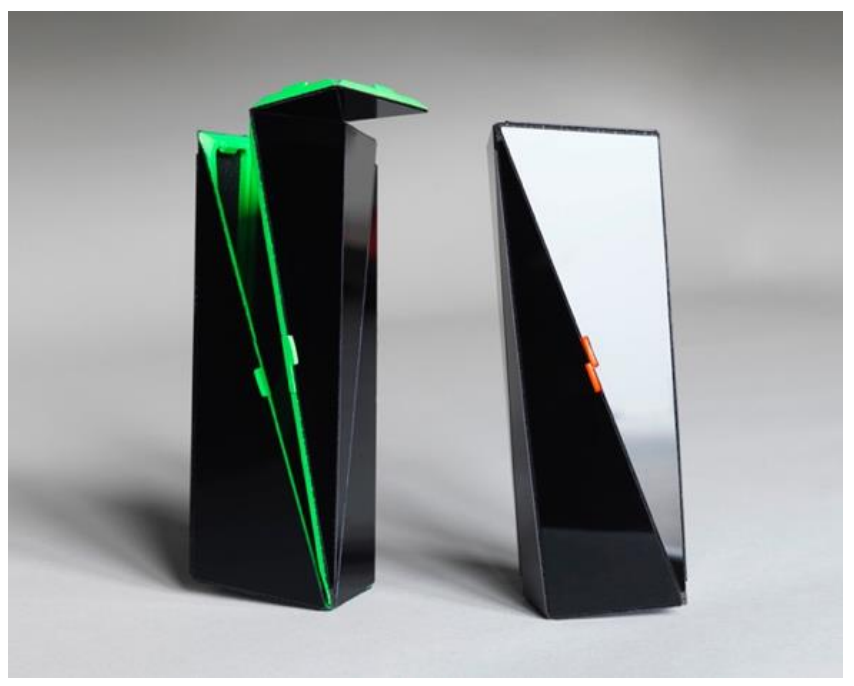

Gambar 24. Desain Clutch Orishiki,

(Sumber:http://design-milk.com/orishiki-by-naoki-kawamoto/)

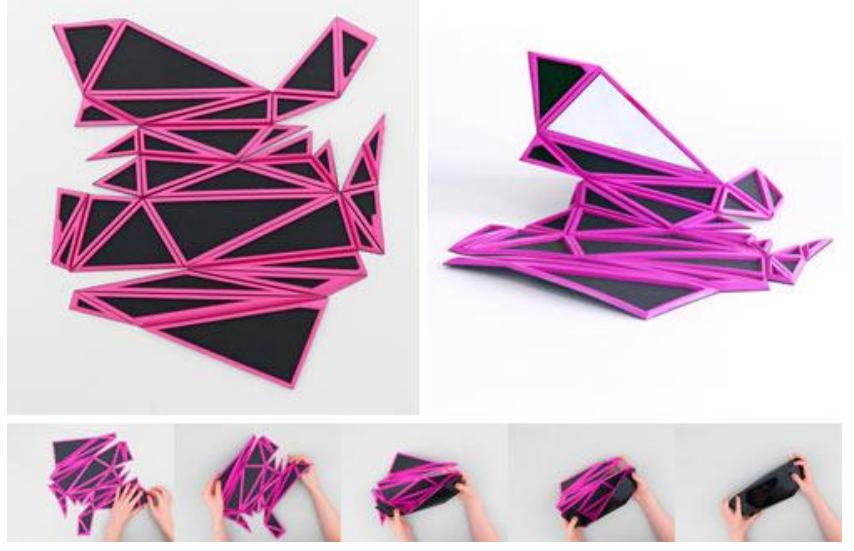

Gambar 25. Tas Orishiki, mengambil konsep dasar seni melipat origami khas Nippon

(Sumber:http://design-milk.com/orishiki-by-naoki-kawamoto/)

Orishiki adalah sebuah kata hibrida yang terdiri dari 'ori', diambil dari Origami, dan 'shiki' diambil dari Furoshiki, Jepang tradisional pembungkus kain yang cukup besar untuk membungkus dan mengangkut barang dan hadiah, serta memakai mereka sebagai selendang. Materi dan sistem yang cukup unik yang merupakan gabungan cara melipat dan menelan atas volume di dalam. Ada kemungkinan besar banyak cara untuk menggunakan sistem yang berbeda jenis bagasi di masa depan.
Selain produk fashion dan apparel, perancangan produk alat transportasi juga banyak yang mengaplikasikan teorema fraktal. Seperti desain ban kendaraan perang yang dikembangkan oleh Pentagon, Amerika Serikat. Ide dasar desain ban tersebut adalah menciptakan rancangan ban anti bocor sintetis yang terbentuk atas struktur fraktal geometris untuk dapat digunakan di seluruh kendaraan tempur tentara Amerika (Gambar 26).

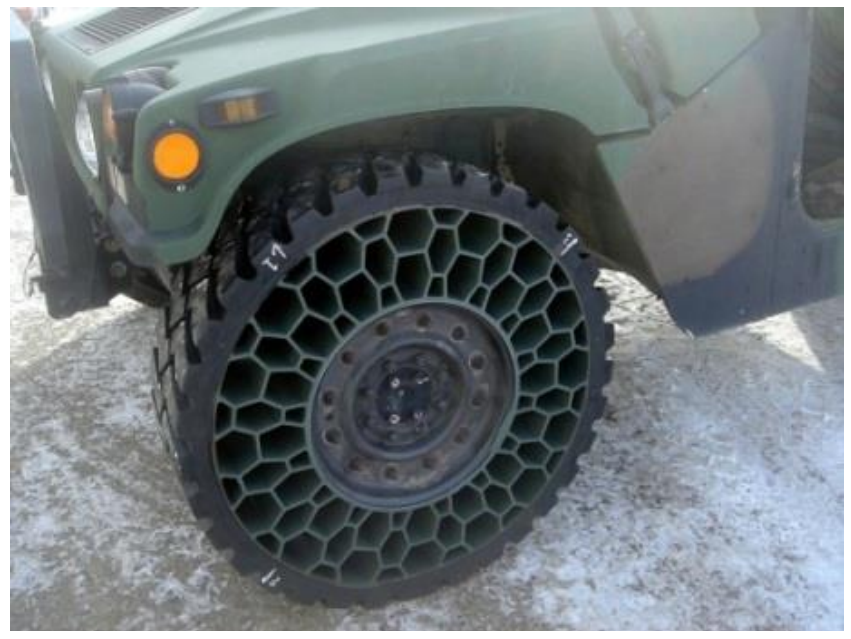

Gambar 26. Model ban anti bocor versi militer tanpa udara dirancang dengan struktur fraktal

(Sumber: http//airless-tire-ban-tanpa-perlu-angin)

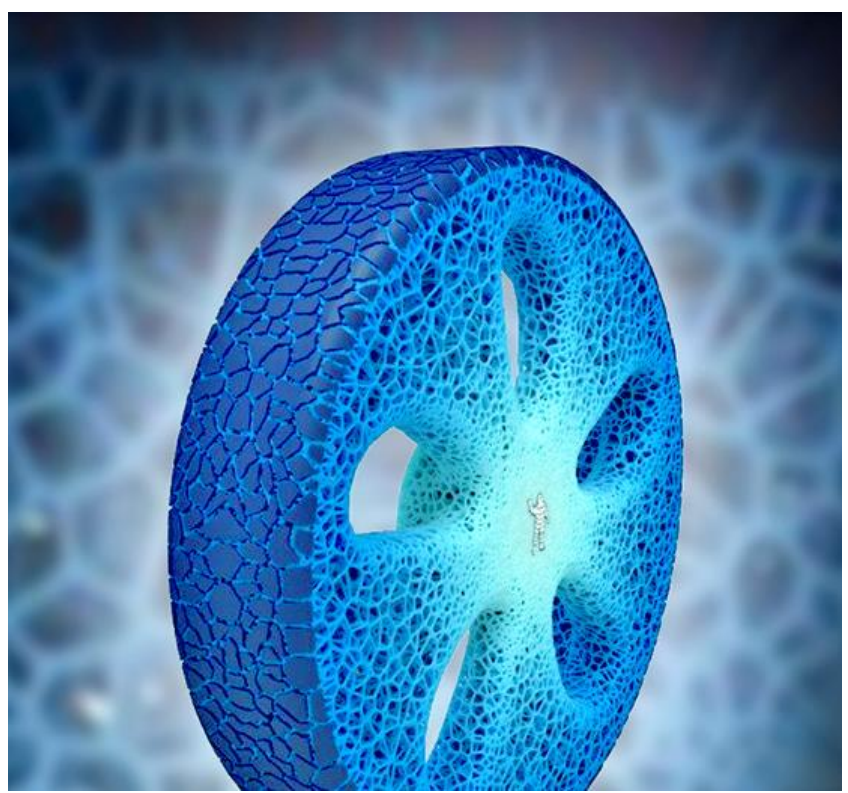

Gambar 27. Fraktal pada pola alur ban air less versi sipil (Sumber: https://www.engadget.com/2017/08/07/ michelin-vision-biodegradable-3d-print-airless-tire/)

Ban kendaraan anti bocor juga dikembangkan untuk non-militer. Struktur fraktalnya terlihat pada Gambar 27. Selain kendaraan tempur darat, Amerika Serikat 
sudah sejak lama mengembangkan proyek pembuatan pesawat tempur anti radar. Salah satunya adalah F117A Nighthawk. F-117 dibangun secara rahasia selama akhir 1970an dan awal 1980an dan tidak dipublikasikan hingga 1988. F-117A Nighthawk adalah pesawat serang darat siluman yang hanya dimiliki oleh Angkatan Udara Amerika Serikat.

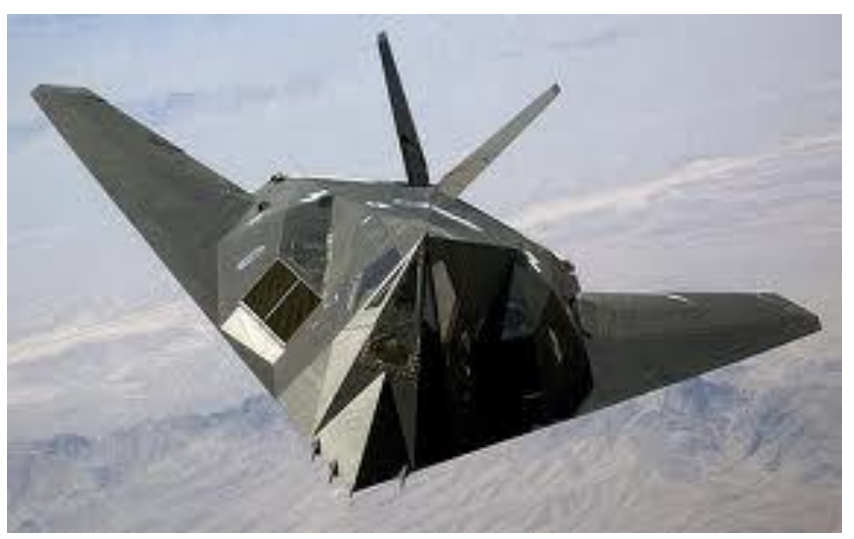

Gambar 28. Pesawat F-117 Nighthawk

(Sumber: https://id.wikipedia.org/wiki/F-117_Nighthawk)

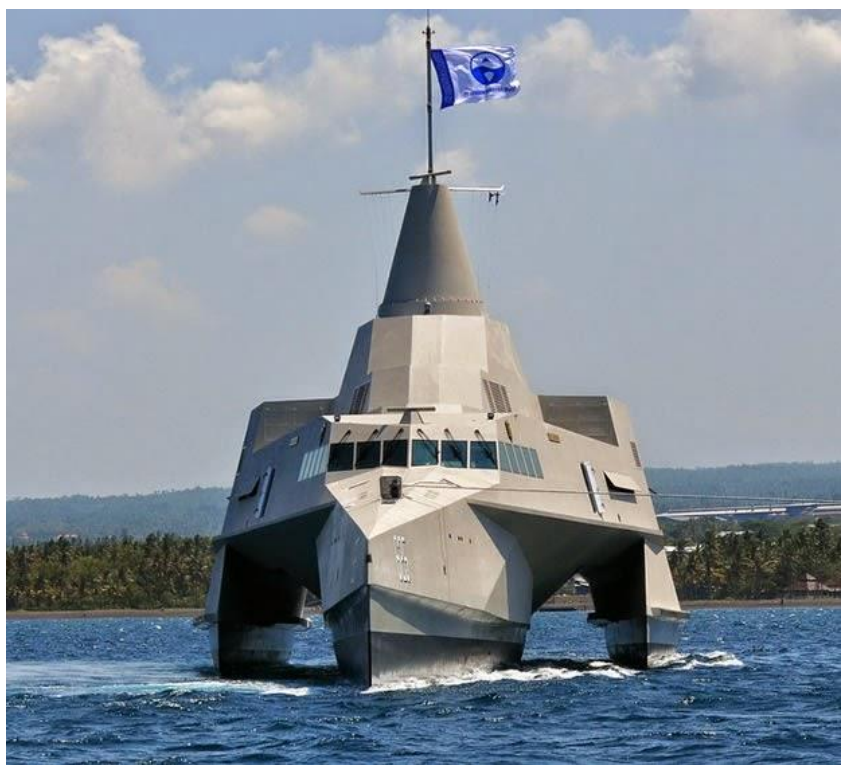

Gambar 29. KRI Klewang, sebuah kapal kelas siluman Indonesia Yang dirancang menggunakan fractal teorema.

(Sumber http://errymath.blogspot.com/2014/08/klewang-classstealth-patrol-ships)

Pesawat ini adalah hasil dari program pesawat siluman Lockheed Have Blue, dan merupakan pesawat pertama yang dirancang khusus untuk menggunakan teknologi siluman. Karakteristik Stealth dari F-117 ditingkatkan dengan menggunakan berbagai jenis pelapisan material penyerap-radar RAM (Radar
Absorban Material) dan lapisan penyerap-radar (radar absorbant screens) yang menutupi inlets mesin yang dipadukan dengan bodi pesawat yang dirancang fraktal geometris (Gambar 28). Ujung pintu dan panel akses seperti roda pendaratan dan ruang tempat bom juga bergigi tajam (serrated) untuk menghamburkan gelombang radar. Kendaraan tempur lainnya yang didesain berbasis teorema fraktal adalah kapal perang. Bahkan kapal perang buatan Indonesia, KRI Klewang, telah dirancang sebagai kapal siluman yang memiliki kemampuan anti radar. Kapal buatan PT Lundin Industry Invest, Banyuwangi, ini secara fisik tampak mengaplikasikan teorema fraktal pada desain bodinya (Gambar 29).

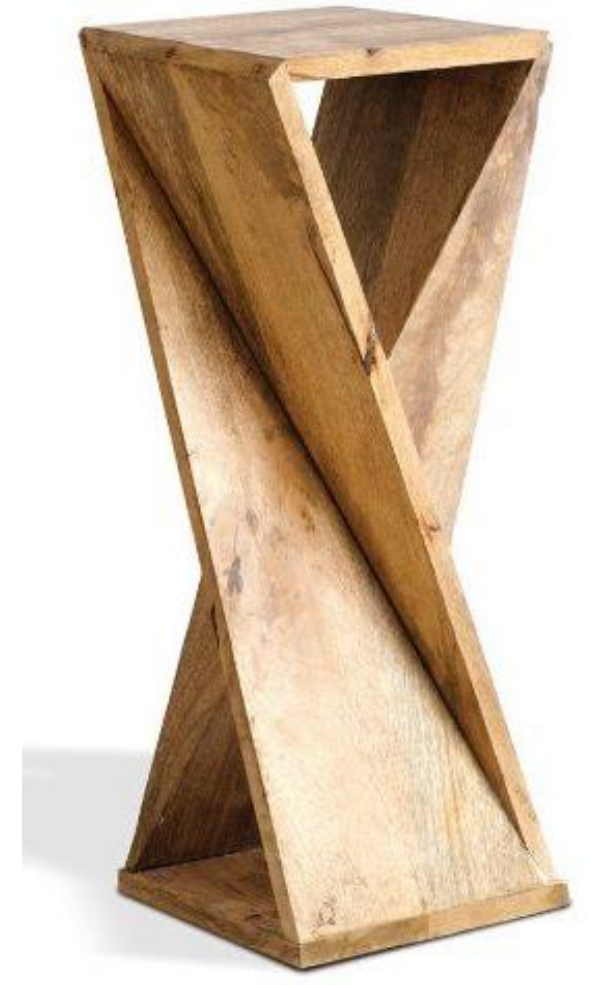

Gambar 30. Fraktal moderen dalam industrial desain furniture (Sumber:http://www.fromupnorth.com/product-industrial-designinspiration-1229)

Desain industri berbasis fraktal juga diterapkan pada industri mebel atau furniture. Hal ini mendorong munculnya desain-desain baru yang tidak disangka sebelumnya (novelty). Model furnitur terbaru yang begitu kompak dan futuristik menjadikan garapan ini tereksplorasi dengan inovasi tanpa batas. Bentuk garapan yang inovatif bahkan dianggap tidak masuk akal, kini dapat diaplikasi dan diusahakan dalam industri berbasis fraktal geometris. 


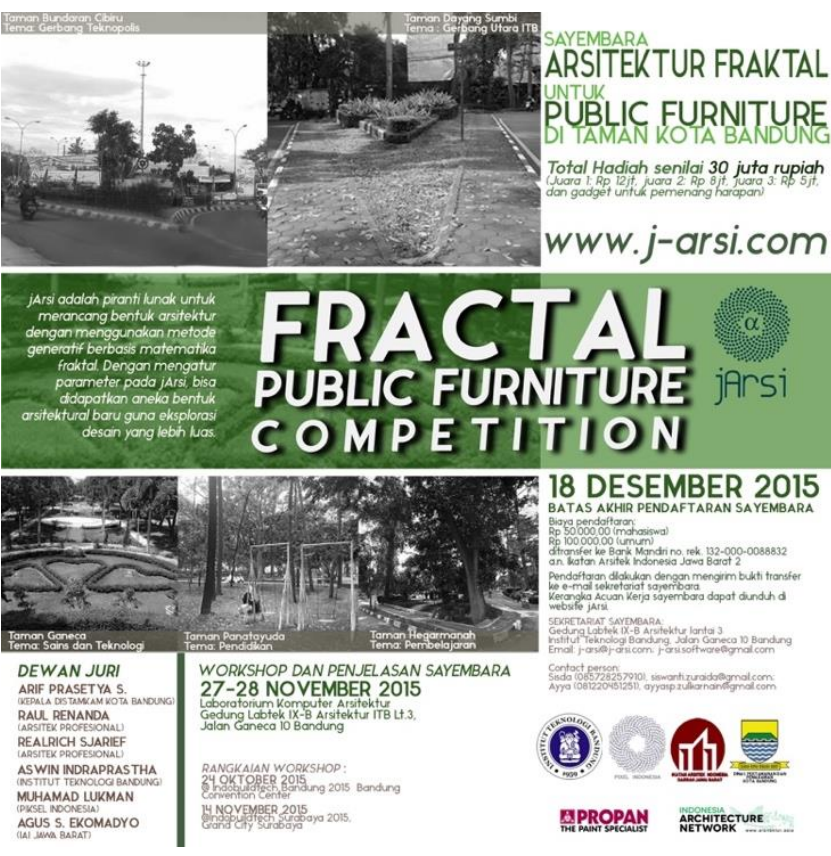

Gambar 31. Kompetisi desain public furniture, fraktal menjadi salah satu acuan penilaian lomba

(https://www.google.com/www.arsitektur.asia/SayembaraFraktal-bandung-public-furniture)

\section{Kesimpulan}

Teorema matematika, dalam penemuan awalnya merupakan upaya manusia dalam hal ini ilmuwan, pemikir, dan pencetus ide mengapa fenomena alam itu muncul dalam alam visual nyata. Sejak lama setelah hal ini dikreditkan kepada kita, barulah eksplorasi akan teorema itu tumbuh dan dikembangkan sebagai bagian dari alam perancangan modern yang tidak hanya membuat takjub, akan tetapi menghasilkan hal-hal baru yang tidak pernah dibayangkan sebelumnya. Ilmu pengetahuan dan teknologi yang semakin maju memudahkan munculnya penemuan-penemuan baru yang pada awalnya sebuah keniscayaan. Industri juga memanfaatkan teorema guna mengisi atau bahkan untuk memecahkan masalah desain industri terkait sumber alam, budaya dan tentunya kebaruan dalam ilmu pengeetahuan itu sendiri (novelty knowledge)
Agusta, Andi (2014) Rekursif atau rekursi (recursion). Retrieved from http://andiagusta.blogspot.com/2014/04/rekursif-ataurekursi-recursion.html 01 Februari 2017 07:32

Barnsley, M. F. (2012). Fractals everywhere. Mineola, N.Y: Dover.

Harris, J. W., \& Stocker, H. (2011). Handbook of mathematics and computational science. New York: Springer

Hofstadter, D. R. (2006). Gödel, Escher, Bach: An eternal golden braid. New York: Basic Books.

Lawson, J. E. (2001). Hands-on science: Characteristics of objects and properties of materials : physical science (matter). Winnipeg: Portage \& Main Press (Peguis Publishers.

Mandelbrot, B. (2006). The fractal geometry of nature. New York: W.H. Freeman and Company.

Pramana, G.J. (2015) Pengertian dan Pola Barisan Bilangan Fibonacci. Retrieved from http://www.rumusmatematikadasar.com/2015/03/pengertiandan-pola-barisan-bilangan-fibonacci.html

Singh, Simon (1998). Fermat's Enigma. New York: Anchor Books

Stribley, Mary (2015) 50 Stunningly Beautiful Geometric Patterns In Graphic Design: Have you made the most out of geometric patterns? Retrieved from https://designschool.canva.com/blog/geometric-design 01 Februari 2017 09:21

Nirvana, Dave (2014) Akhirnya, semua jadi KOMPAS TV. Retrieved from https://davenirvana1.wordpress.com/2014/02/ 02 Februari 11:12

\section{Daftar pustaka}

